\title{
Magmarizm and Ore Occurrences of the Kakheti and Tusheti Regions, Greater Caucasus, Georgia Republic
}

\author{
A. Okrostsvaridze ${ }^{1}$, K. Aqimidze ${ }^{2}$ and N. Gagnidze ${ }^{3}$ \\ 1. Faculty of Natural Sciences and Engineering, Ilia State University, 3/5 Cholokashvili Av., 0162 Tbilisi, Georgia \\ 2. Faculty of Natural Science, Javakhishviuli State University, 1 Chavachavadze Av., 0138 Tbilisi, Georgia \\ 3. Al. Janelidze Institute of Geology, Tbilisi State Universitety, 15 Polikovskaia St., 0172 Tbilisi, Georgia
}

\begin{abstract}
Kakheti and Tusheti regions (Eastern Graeter Caucasus), of the Georgia Republic are mainly underlain by highly deformed Lower-Middle Jurassic shales, sandstones, and volcaniclastic rocks, intruded by numerous intrusive bodies of various compositions. All units contain a variety of ore mineral deposit types and their surrounding zones of hydrothermal alteration. Continued geological and metallogenic researches in the past 30 years have led to important new information regarding the evolution of this region. Three main stages of magmatic activity are now clearly distinguished. Oldest magmatism comprises Early Jurassic events, related to extensional tectonism, which ranged from rhyolitic, through dacitic and andesitic, and to basaltic magma. Additional extensional processes (in Bajocian) were characterized by intrusion of a gabbro and diorite dike system into recently deposited late Early Jurassic-early Middle Jurassic formations. The final magmatic event was associated with Middle Jurassic folding and uplift during which multiphase diorite plutons were emplaced. Related intense hydrothermal activity was responsible for important polymetallic mineralization, with more than 100 recognized outcropping ore occurrences. A detailed study of 11 of these ore occurrences has indicated anomalous concentrations of gold, thorium, yttrium, cobalt, cadmium, and bismuth. In addition, several new and potentially significant ore mineral occurrences were discovered.
\end{abstract}

Key words: Magmatism, ore occurrences, Kakheti and Tusheti regions.

\section{Introduction}

In this work we have studied complex magmatism, known as ore systems and describe new ore mineralized areas in the Kakhet and Tusheti regions (Eastern Greater Caucasus), of the Georgia Republic. More than 100 pyrite-pyrrhotite and copper-polymetallic mineralized occurrences of varied size are recognized in this region, and they include disseminations, veins, and massive sulfide bodies. The significance of our research on the mineral occurrences of the region is particularly well justified because in neighboring Azerbaijan, along the southern slope of the Greater Caucasus, important stratiform pyrite-copper-polymetallic deposits (e.g., Katsdag, Filizchay, and Katekh) were discovered in the 1960s [1]

Corresponding author: Avtandil Okrostsvaridze, Ph.D., professor, research fields: natural sciences, earth sciences. in rocks that continue into the Georgia Republic. Also, almost at the same time and on the northern slope of the Greater Caucasus in Dagestan (Russian Federation), the Kizil Dere copper-polymetallic deposit was put into production [2]. Subsequently in the 1970s, after discovery of the deposits in Azerbaijan and Dagestan, a large-scale geological exploration program for nonferrous metals was carried out in the Georgian part of the Greater Caucasus. However, despite the high favorability for new mineral resources, the program was not successful in identifying important new deposits in Georgia.

In the Kakhet and Tusheti regions, after almost 30 years with relatively no metallogenic research, we carried out new geological work to address potential resource favorability. In particular, our work included a more detailed geological reconstruction of the region, defining magmatic and post-magmatic hydrothermal 
events and examining the mineral occurrences of the region. Analysis of the relevant data allowed us to make essential corrections to the pre-existing geological understanding of the region, and, in particular, important new points on the regional metallogeny were demonstrated.

\section{Field Sampling and Analytical Methods}

During geological field work more than 200 of magmatic rocks samples were collected for petrographic study, about 700 samples were collected for geochemical anlayses, and 8 samples of magmatic rocks were selected for isotopic dating. Geochemical samples, each about 3-4 kg, were taken from individual locations, although larger 5-6 $\mathrm{kg}$ samples were collected for the geochronology work. All samples were collected and plotted on topographic maps by using GPS. Major element analyses, and petrographic and mineralogical description of rocks were carried out at the geological laboratory of Tbilisi State University. Isotopic dating of zircons (U-Pb method,) and measurement of trace elements concentrations of some samples were conducted at the laboratory of the Geology Department of Taiwan National University (LA-ICP-MS method). Geochemical analyses for many metals were conducted at AcmeLabs inVancouver, Canada, using as well LA-ICP-MS methods, and also at chemical laboratory of CMG Gold Ltd by atomic absorption spectrometry.

\section{Brief Geology of the Region}

The Caucasus represents a Phanerozoic collisional orogen that formed between the southern continental margin of the Eurasian plate and the Arabian plate, and it extends for more than $1,200 \mathrm{~km}$ from the Caspian to the Black Sea. Three major units are distinguished in the Caucasus, which include the Greater and Lesser Caucasian mobile belts and the inner Caucasian microplate. The Greater Caucasus belt is the northernmost part of the Caucasus orogen, which is accreted to the south margin of the Eurasian continent. It is a complexly folded series of nappes. The two major sequences resulting from its construction are distinguished as the pre-Mesozoic crystalline basement and Mesozoic-Cenozoic sedimentary and volcanic-sedimentary cover [3].

The Eastern Greater Caucasus in Georgia (Fig. 1), which is approximately $25-40 \mathrm{~km}$ in width, can be traced for about $125 \mathrm{~km}$, from the Iori-Alazani watershed in the east to the Mazim-Chay River valley near the Azerbaijan border. Its northern border runs along the southern boundaries of Dagestan and Chechnya, and to the south is separated from the Alazani River depression by a regional fault system. The entire area covers approximately $3,900 \mathrm{~km}^{2}$. According to the Caucasus geotectonic zoning, the Gerogian segment is located within the Main Range zone to the north and the Kazbegi-Lagodekhi zone to the south [4].

On the southern slope of the Greater Caucasus, our study area is outcropped by the Alazani River and its tributaries that include the Makhvali, Stori, Didi Khevi, Lopota Rivers and others of the Kakheti region. On the northern slope, the area is outcropped by the Tusheti Alazani River and its tributaries in the Tusheti region. The sedimentary cover of both slopes generally does not differ from each other and is mainly represented by highly folded Lower-Middle Jurassic terrigenous schists, shales, and sandstones, and dacite-andesite-basalt volcanic formations. Numerous intrusive bodies of different composition and size were emplaced into the sedimentary cover rocks. All rocks have experienced extensive faulting, brecciation, hydrothermal alteration, and metallic mineral deposition. It is important to note that it is very difficult to conduct fieldwork within the study area because the southern slope of the Greater Caucasus (Kakheti region) is covered with dense forest, and the northern slope (Tusheti Region) is mainly poorly exposed due to the alpine vegetation. 


\section{Greater Caucasus, Georgia Republic}

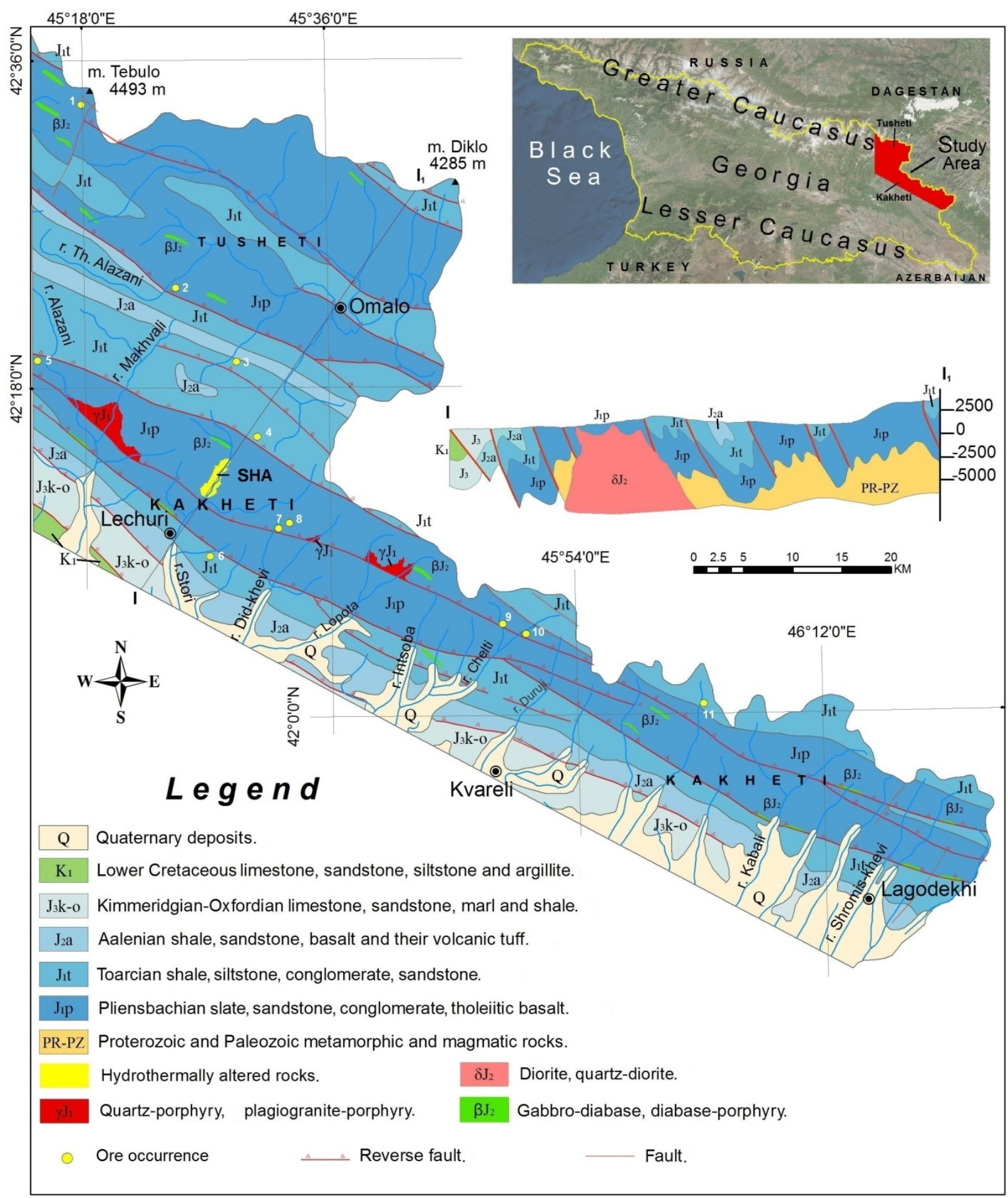

Fig. 1 Geological map of the Kaheti and Tusheti regions of the Greater Caucasus, with mineral occurrence, adapted after Ref. [5].

Main ore occurrences: 1-Tebulo, 2-Ilurta, 3-Satskhvre Khorkhi, 4-Abano, 5-Qvachadala, 6-Lechuri, 7-Samchedlo, 8-Englisuri, 9-Lodvani, 10-Chelti and 11-Shorokhevi. HA-Stori hydrothermal altetation zone. 


\subsection{Sedimentary Cover}

The sedimentary cover of the eastern Greater Caucasus in the Georgian segment is mainly represented by a thick series of Lower-Middle Jurassic shales and sandstones, with thinner sequences of volcanogenic-sedimentary formations. The series of sedimentary rocks is explosed within a regional anticline structure, which is traced in a NW-SE direction and is overturned to south. The series of rocks were deposited as a result of major rifting and subsidence in the Paleozoic basement, which resulted in formation of a marginal sea environment. Some small fragments of this basement outcrop on the southern slope in deeply cut canyons.

The Stori suite was considered to be the oldest sedimentary formation in the region, which was subdivided by Ref. [6]. According to this work, the suite represented alternating Sinemurian (ca. 200-190 Ma) shales and coarse-grained arkosic sandstones. Subsequently it was discovered that the coarse-grained sandstones actually are bodies of tectonized subvolcanic quartz porphyries, plagiogranite porphyries, and granite porphyries, which cut Lower Jurassic strata that includes Pliensbachian (ca. 190-183 Ma) shales [7]. Fragments of such formations outcrop along the crest of the anticline in the sedimentary sequence. In some locations, magmatite is the main lithology, but because of poor exposure and inaccessibility it is difficult to define their thickness.

In the Eastern Greater Caucasus, the oldest sedimentary rocks dated by fauna are Pliensbachian shales and clay-rich shales, which contain interlayers of fine-grained sandstones, siltstones, and rarely carbonate rocks. Pliensbachian ammonites were found in the calcareous sandstones [6]. Also subalkaline basalt sheets are present in the suite. The total thickness of the suite is approximately $1,000 \mathrm{~m}$ [8].

The suite of Pliensbachian rocks gradually grades upward into rocks of the Toarcian (ca. 183-174 Ma) sedimentary complex, also dated by fauna, which is mainly represented by flysch and sandstones. These sediments are traced for almost the entire length of the Kakheti region and are bounded above by rocks of the Duruji suite. The total thickness of the suite is about $1,100 \mathrm{~m}$ [9]. The sections of Early Jurassic sedimentary rocks in the eastern Caucasus are gradually followed upward by the Aalenian (ca. 174-170 Ma) Formation, which conformably overlies the rocks of the Toarcian complex, and is dated by fauna. The suite is represented by fine-grained sandstones, argillites, and black shales. In some areas andesite and basalt sheets and associated tuffs are exposed. The total thickness of the suite is determined to be about $800-900 \mathrm{~m}$ [8]. The youngest rocks in the sedimentary series are Oxfordian (ca. 163-157 Ma) clastic limestones and Lower Cretaceous sandstone turbidites and limestones, which are preserved fragmentally at the boundary between the Greater Caucasus southern slope and the Alazani depression.

The sedimentary cover is usually intensely deformed with widespread cataclasites, mylonitization, hydrothermal alteration, and sulfide mineralization (Fig. 2). These features are well developed in the Stori River canyon, where the hydrothermal alteration can be traced for a distance of $4 \mathrm{~km}$. Because of the intense alteration, the sedimentary rocks here are commonly impossible to define. In the highly altered section of the canyon, many of the sedimentary rocks have been transformed to albite-quartz-epidote-chlorite and quartz-sericite-chlorite assemblages. These altered rocks almost always contain some pyrite, rare pyrrhotite, and very rare chalcopyrite.

\section{Magmatism}

Magmatic rocks are very significant in the geologic evolution of the Kakheti segment of the Greater Caucasus. Mesozoic subvolcanic and intrusive bodies of different compositions have played an important role in formation of the hydrothermal alteration of the 
sedimentary cover and deposition of the sulfide mineral

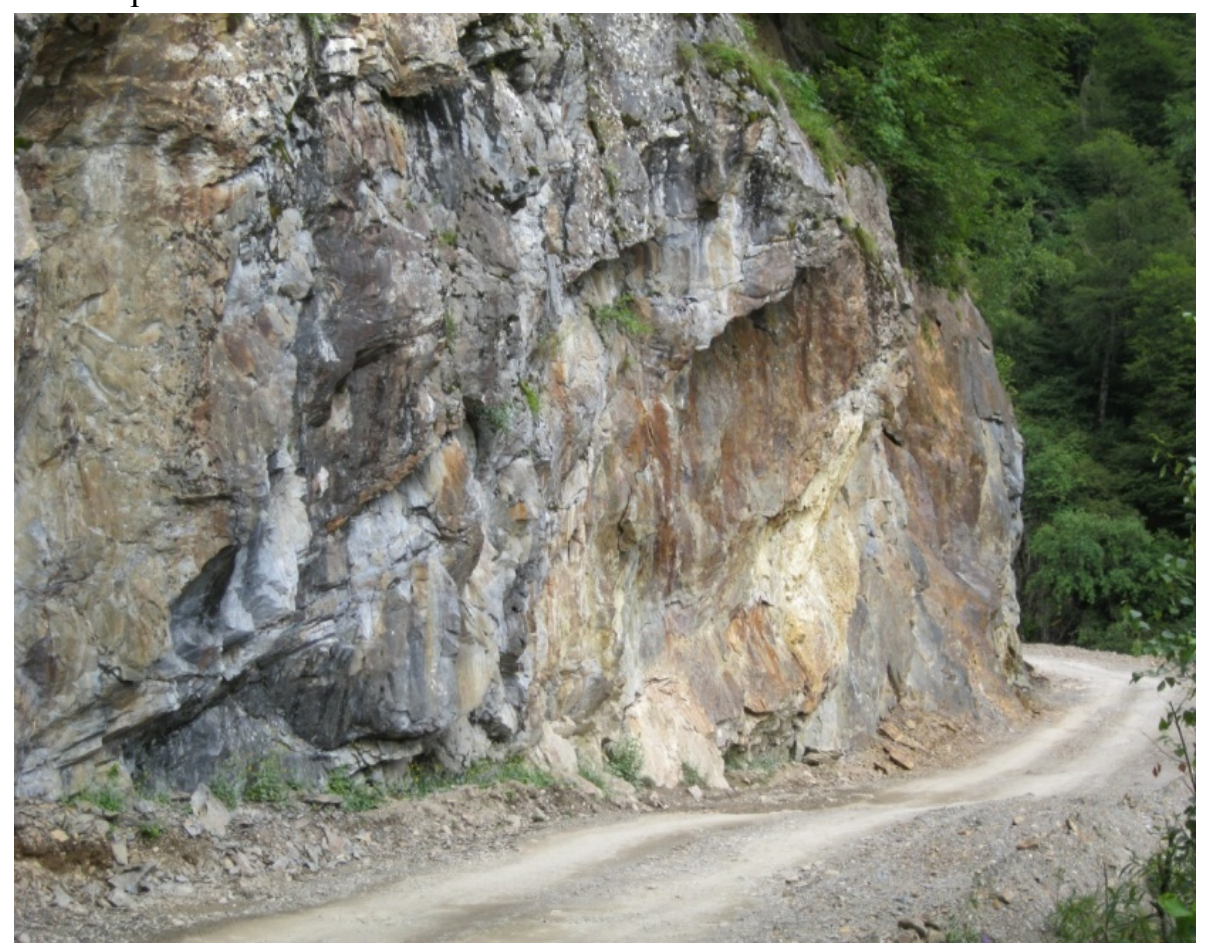

Fig. 2 Crushed and hydrothermaly altered Pliensbachian shales of the Stori canyon.

occurrences. However, small fragments of Paleozoic basement are also exposed in the Stori River canyon, which are in tectonic contact with the Jurassic sediments. We dated cataclastically deformed plagiogranite porphyries that comprise some of the fragments by $\mathrm{U}-\mathrm{Pb}$ on zircons at Taiwan National University. The resulting ages are: Sample \#11Ge03 = $313 \pm 8 \mathrm{Ma}-$ Makhvali river outfall; Sample \#11Ge05 $=312 \pm 3 \mathrm{Ma}$-Stori river source; Sample \#11Ge100 = $317 \pm 2 \mathrm{Ma}-$ Stori river canyon.

Our data suggest that, in Mesozoic period, the first major magmatic activity in the region began in Early Jurassic. It was linked to basement extension and rifting processes, and products include quartz porphyries, plagiogranite porphyries, and granite porphyries that intrude the shales and sandstones of Early Jurassic age.

Pyroclastic rocks of rhyolite and dacite composition are widespread in the Early Jurassic sediments. They represent the extrusive equivalents of the above noted subvolcanic bodies. In some locations, felsic magmatic rocks are dominant over the sedimentary rocks, such as in the Speroza Mountains and in outcrops along the Lopota River. During the last stage of this magmatic activity, thick basalt sheets were formed, which are mostly represented by lava-breccias and pillow lavas. The best outcrops of pillow lavas, with thicknesses of 200-300 m, are defined in the Alazani, Quachadala, Ilto, and Srori River canyons (Fig. 3).

The second major magmatic activity in the region is marked in Bajocian (ca. 170-168 Ma), which is related to further extension of the newly formed crust. Products of this magmatic activity are shallow basic intrusions, which were emplaced into rocks of the Lower Jurassic Aalenian Formation. They appear as gabbro-diabase and diabase porphyry dike systems. These dikes have thickness up to 0.3-30 $\mathrm{m}$ at modern erosion level, and can be traced for tens to hundreds of meters along strike. They are commonly localized along fault zones and are widely distributed. Based upon our petrographic studies, these rocks are mainly represented by hornblende and augitic diabases in which hornblende has widely replaced pyroxene. They may be genetically linked to one single large magmatic 


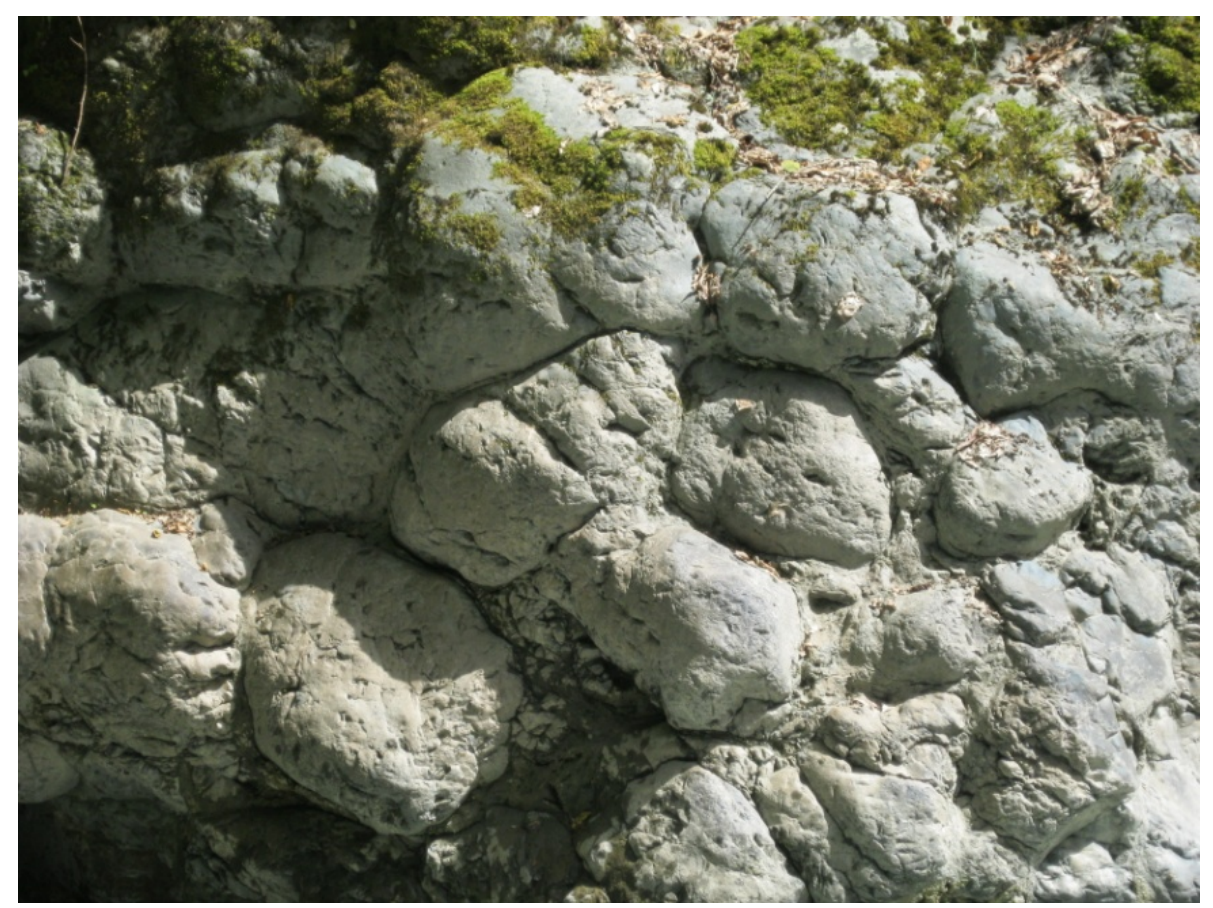

Fig. 3 Early Jurassic pillow lavas in the Stori canyon.

center. As for the impact of the diabase dikes on their surrounding wallrocks, as well as regarding their ore-forming potential, there is no evidence of any associated important hydrothermal activity.

The third major magmatic activity in the region was during Bathonian (ca. 168-166 Ma) time, which is represented by multiphase plutonic bodies. Fragments of silicified diabases are contained in younger magmatic rocks. Only small parts of these plutonic bodies are outcropping (Fig. 4), as they have yet to be widely exposed by erosion. They mainly are composed of plagioclase, hornblende, quartz, epidote, chlorite, sulfide minerals (pyrite, chalcopyrite, pyrrhotite, sphalerite), sphene, and zircon.

The main phase of the third magmatic activity is represented by diorite and quartz-diorite (Table 1). The REE distribution patterns of these rocks show that they have not been fractionated (Table 2; Fig. 5). However, in the exposed apical parts of these bodies, numerous stocks, have average felsic compositions, present in Table 1. The mineralogy of the felsic rocks is simple and they are generally composed of quartz, plagioclase, and local minor potash feldspar and sericite. It should be noted that in contrast to the main and rare earth elements, by content of trace elements and variations, quartz-diorite and felsic phases do not greatly differ from each other (Table 3; Fig. 6).

Summarizing the data on magmatism in the Eastern Greater Caucasus region of Georgia, there are clearly three major stages. The first magmatic activity was associated with crustal subsidence, extension and rifting in Early Jurassic. Associated magmatic rocks varied in composition from rhyolite, to dacite, and through to andesite and basalt. The second significant magmatic event, which was linked to the extension of the newly formed crust, during which the Aalenian sediments were deposited in Bajocian time, was characterized by basic intrusions and formed a gabbro-diabase dike system. The third period of magmatic activity is associated with the Bathonian folding and uplifting, when multiphase dioritic plutons intruded the sedimentary cover, which caused intense hydrothermal alteration of the country rocks, including extensive areas of propylitic and phyllic alteration and mineralisation. 
Greater Caucasus, Georgia Republic

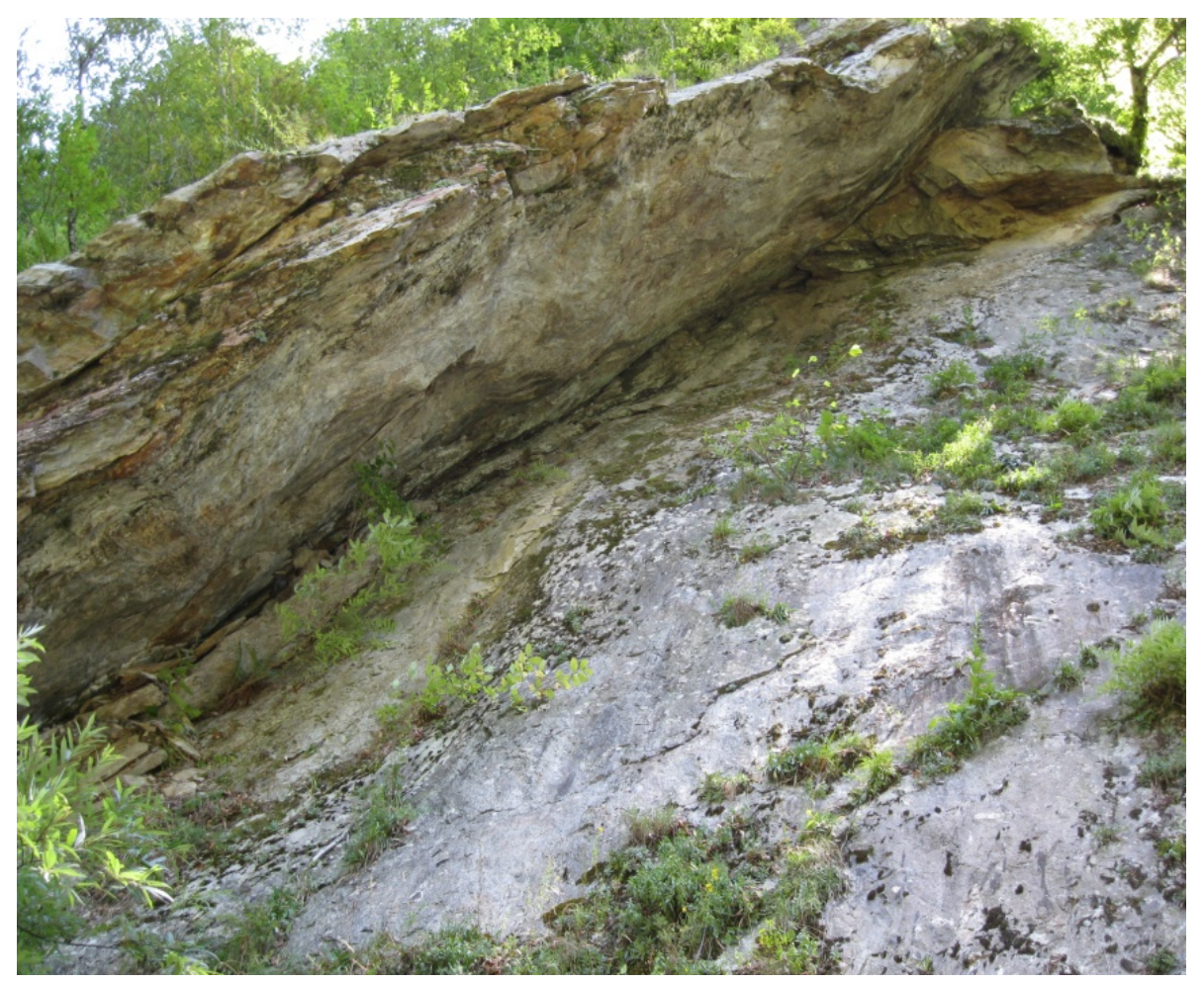

Fig. 4 Activ contac of quartz-diorate body with Pliensbachian shales in the Stori canyon.

Table 1 Major element chemical analysis (wt\%) of the Stori Canyon multiphase pluton.

\begin{tabular}{lllllllllllll}
\hline $\mathrm{Sm} . \#$ & $\mathrm{SiO}_{2}$ & $\mathrm{TiO}$ & $\mathrm{Al}_{2} \mathrm{O}_{3}$ & $\mathrm{Fe}_{2} \mathrm{O}_{3}$ & $\mathrm{MnO}$ & $\mathrm{MgO}$ & $\mathrm{CaO}$ & $\mathrm{Na}_{2} \mathrm{O}$ & $\mathrm{K}_{2} \mathrm{O}$ & $\mathrm{P}_{2} \mathrm{O}_{5}$ & LOI & Sum \\
\hline $\mathrm{STJC}$ & 58.03 & 0.63 & 18.59 & 7.76 & 0.11 & 1.21 & 3.90 & 3.47 & 1.27 & 0.29 & 3.02 & 99.88 \\
$\mathrm{SICP}$ & 61.45 & 0.73 & 17.25 & 7.79 & 0.11 & 2.29 & 2.83 & 2.60 & 2.48 & 0.23 & 3.73 & 100.49 \\
$86-09$ & 78.03 & 0.18 & 13.87 & 2.23 & 0.01 & 0.56 & 1.35 & 1.46 & 2.20 & 0.07 & - & 99.95 \\
\hline
\end{tabular}

SICP and STJC-quartz-diorites; 86-09-plagiogranite-porphiry.

Table 2 Rare earth elements chemical analysis (ppm) of the Stori Canyon multiphase pluton.

\begin{tabular}{lllllllllllllll}
\hline Sm. \# & $\mathrm{La}$ & $\mathrm{Ce}$ & $\mathrm{Pr}$ & $\mathrm{Nd}$ & $\mathrm{Sm}$ & $\mathrm{Eu}$ & $\mathrm{Gd}$ & $\mathrm{Tb}$ & $\mathrm{Dy}$ & $\mathrm{Ho}$ & $\mathrm{Er}$ & $\mathrm{Tm}$ & $\mathrm{Yb}$ & $\mathrm{Lu}$ \\
\hline STJC & 62.2 & 114.0 & 12.2 & 42.8 & 7.01 & 1.91 & 5.27 & 0.75 & 3.89 & 0.78 & 0.33 & 0.33 & 2.26 & 0.36 \\
SICP & 39.6 & 76.1 & 8.71 & 32.4 & 6.01 & 1.59 & 5.06 & 0.74 & 4.02 & 0.81 & 0.34 & 0.34 & 2.22 & 0.34 \\
$86-09$ & 14.5 & 29.5 & 3.51 & 12.6 & 2.55 & 0.35 & 2.20 & 0.36 & 2.18 & 0.47 & 0.24 & 0.24 & 1.56 & 0.24 \\
\hline
\end{tabular}

Table 3 Trace elements chemical analysis (ppm) of the Stori Canyon multiphase pluton.

\begin{tabular}{lllllllllllllll}
\hline Sm. \# & Sc & V & Cr & Co & Ga & Sr & Y & Zr & Nb & Cs & Hf & Ta & Th & U \\
\hline STJC & 17.7 & 138 & 120 & 13.5 & 20.0 & 543 & 22.6 & 184 & 13.7 & 10.7 & 3.90 & 0.92 & 15.0 & 2.86 \\
SICP & 15.9 & 150 & 154 & 10.6 & 17.7 & 422 & 23.0 & 155 & 12.4 & 4.29 & 3.61 & 0.89 & 13.36 & 1.98 \\
$86-09$ & 21.2 & 21.2 & 131 & 2.78 & 12.4 & 43.2 & 14.2 & 115 & 6.53 & 4.03 & 3.20 & 0.73 & 10.8 & 2.63 \\
\hline
\end{tabular}




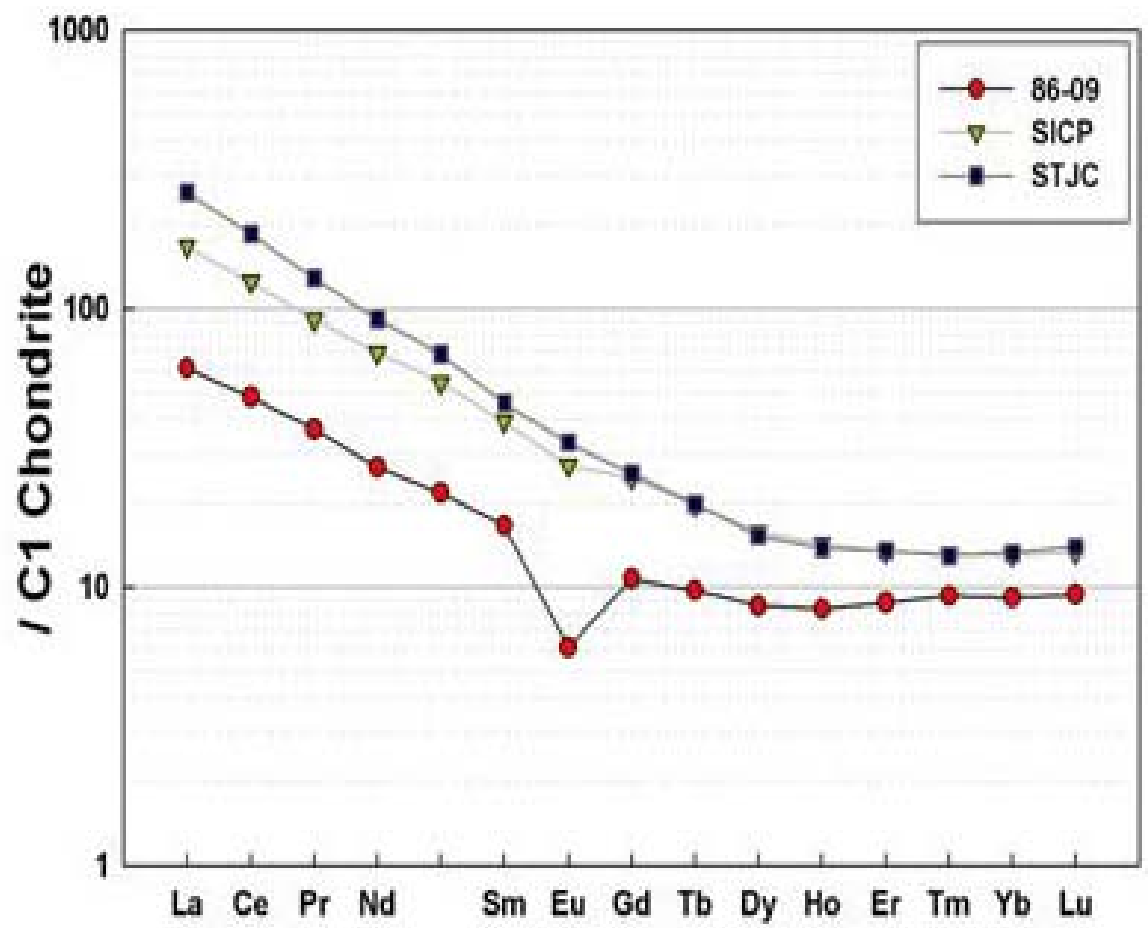

Fig. 5 Sample-chondrite normalised REE diagram, for Stori Canyon multiphase pluton. (SICP and STJC-quartz-diorites; 86-09-plagiogranite-porphiry).

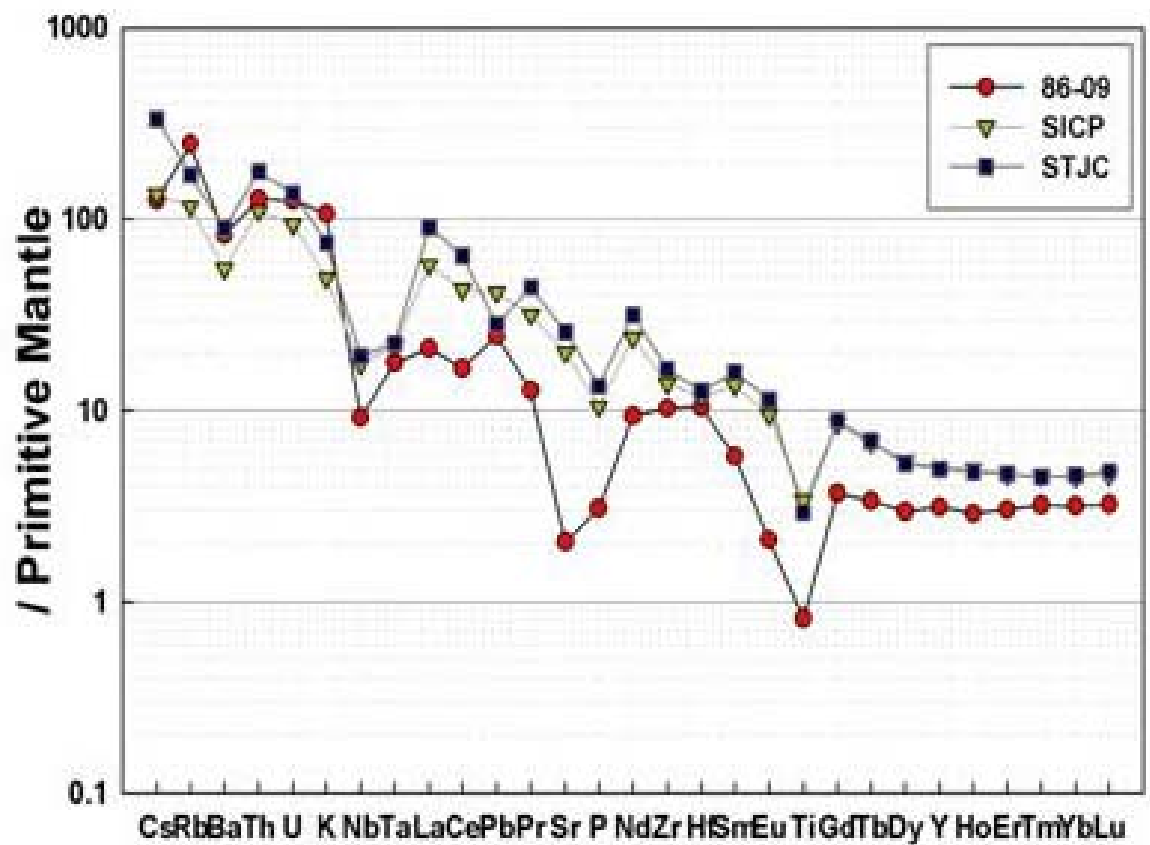

Fig. 6 Sample-primitive mantle normalised trace elements diagram, for Stori Canyon multiphase pluton. (SICP and STJC-quartz-diorites; 86-09-plagiogranite-porphiry). 


\section{Ore Occurrences}

Research on the ore occurrences in the Kakheti and Tusheti regions of the Greater Caucasus began in the early 1900s. Today, in our studied area, more than 100 sulfide-bearing ore occurrences are recognized. These lode deposits include disseminations, veins/veinlets, or bodies of massive sulfide. In places, disseminations and veins may grade into more massive sulfide bodies. Metallic mineralization is preceded by hydrothermal alteration and silicification of wallrocks, during which quartz-sericite-chlorite

and albite-quartz-epidote-chlorite-carbonate assemblages are formed. Later fracturing of these altered rocks has led to deposition of quartz-pyrite-pyrrhotite, quartz-chalcopyrite, and relatively late quartz-calcite-polymetallic assemblages from metal-bearing hydrothermal fluids (Fig. 7).

We have studied in detail the historic mineral occurrences of Tebulo, Ilurta, Satskhvre Khorkhi, Abano, Quachadala, Artana, Loduani, Chelti, Shorokhevi, and Areshi. In addition to these, we conducted the first scientific observations and studies of several recently discovered mineral occurrences. These include those of the Stori River area in a large hydrothermally altered area (e.g. Gelia, Bendena and Thorium zone), which we have combined under the name of Stori district. Also near the village of Lechuri, we examined what we refer to as newly defined Lechuri mineral occurrence. In this present paper, we characterize some of our important new observations on the metallogeny.

\subsection{Kakheti Region}

Stori district: The Stori district represents a broad area of altered rocks within the Stori River canyon. The zone is developed on the southern slope of the Greater Caucasus in the Stori River canyon and was traced for about $3.5 \mathrm{~km}$ until reaching the Abano bridge over the Stori River. The zone is cut by the Pshaveli-Omalo road, which made access possible for this study (Fig. 8).

The hydrothermal alteration in the district is developed within the Pliensbachian shales and sandstones. Along the length of the 4-km-long road there are only five sections of rocks, with a cumulative

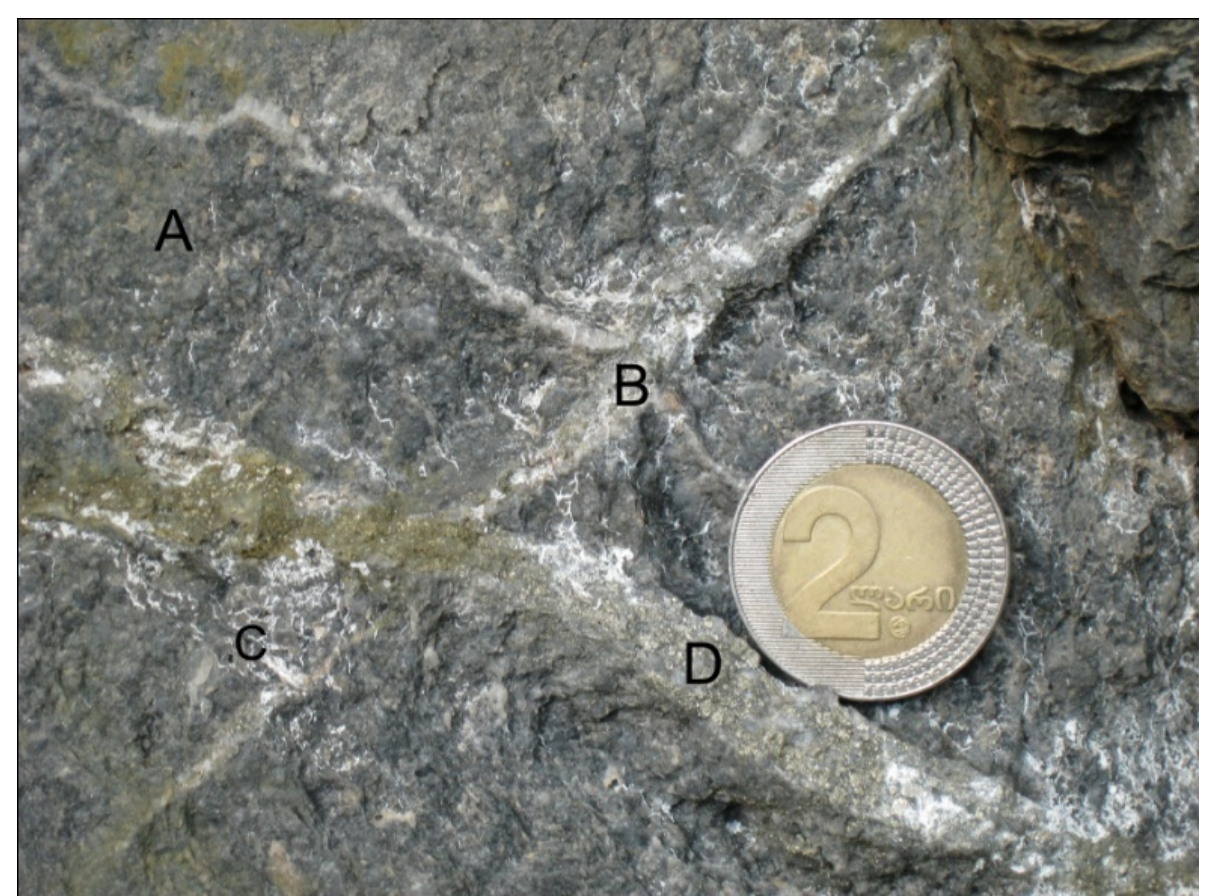

Fig. 7 Silicified and ore mineralized Pliensbachian shale, Stori River canyon.

A—silicified and carbonatized shale; B—quartz vein, C—carbonate veinlets, D—quartz-pyrite-pyrrhotite vein. 


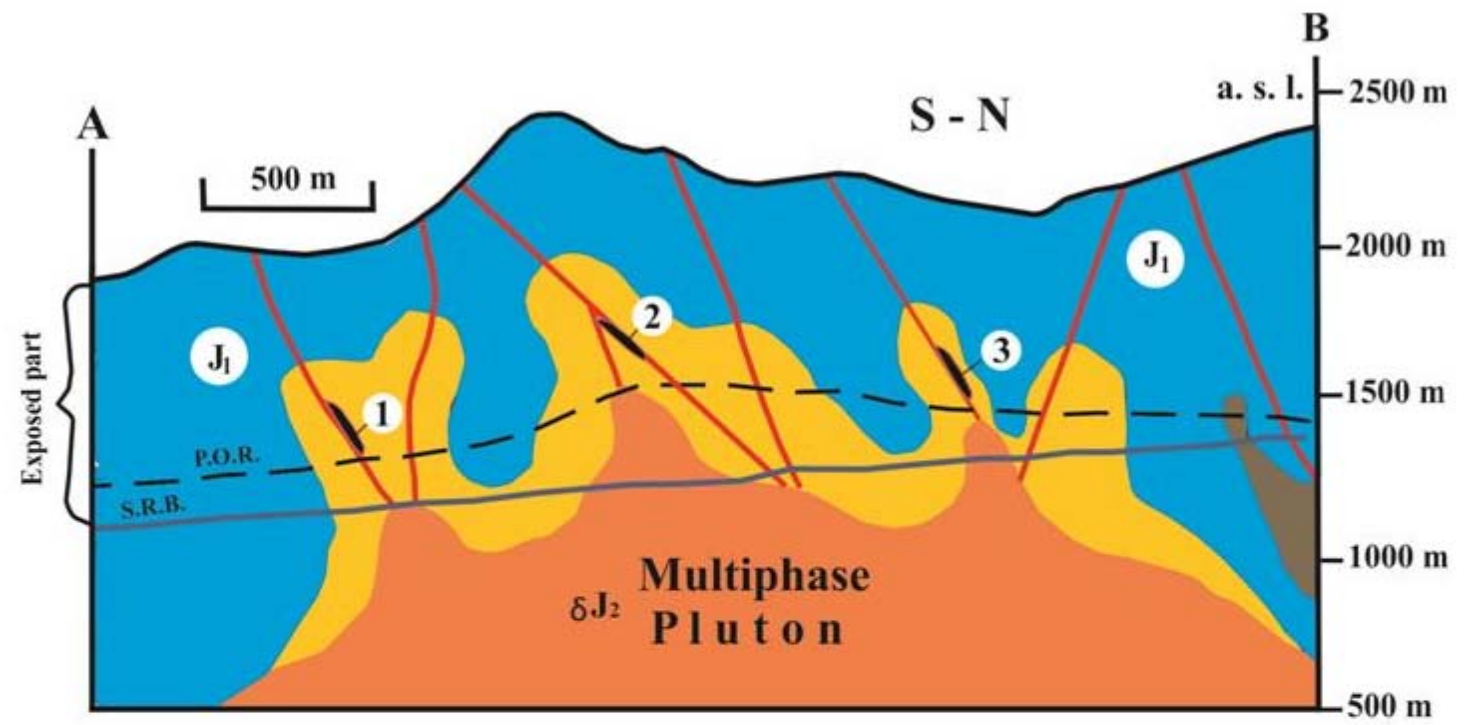

Hydrothermally altered rocks (quartz+cericite+chlorite+pyrite; albite+quatz + epidote+chlorite+pirite)

Bathonian multiphase pluton (diorites, quartz-diorites, diorite-phorphyries, quartz-phorphyries, plagiogranites-phorphyries)

$\beta J_{2} \quad$ Bajocian gabbro-diabase, diabase-phorphyries

$\mathrm{J}_{1}$ Pliensbachian stage, slate and clay shales with intercalationes of sandstones and siltstones

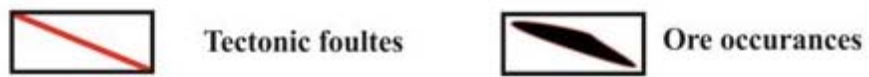

Fig. 8 Schematic cross section (A-B) of the Stori canyon hydrothermal altetation zone $\left(A=N 2^{\circ} 12^{\prime} 968^{\prime \prime}, \quad E 4^{\circ} 29^{\prime} 079^{\prime \prime}\right.$; $B=$ N 42 ${ }^{\circ} 13^{\prime 953} 3^{\prime \prime}$, E $\left.45^{\circ} 29^{\prime} 079^{\prime \prime}\right)$.

Mineral occurrences: 1-Bendena, 2-Gelia, 3-Thorium. (P.O.R.-Phshaveli-Omalo road; S.R.B.-Stori River bed).

length of $1.5 \mathrm{~km}$, that preserve recognizable sedimentary rock protolith features. The altered rocks mainly comprise quartz-sericite-chlorite and quartz-albite-chlorite-epidote assemblages, which also contain abundant pyrite that indicates fluids were rich in iron and sulfur. These rocks are easily distinguished because of their reddish, yellow, and grey colors (see Fig. 2). We interpret the alteration to represent typical phyllic and propylitic assemblages that tend to develop surrounding large-scale porphyry $\mathrm{Cu} \pm \mathrm{Au}$, Mo mineral deposits [10].

More than 200 rock samples collected along the length of the Stori district were analyzed for gold by
ICP-MS, but results did not generally indicate any significant precious metal targets. However, in the northern part of the district, four zones that are several tens of meters thick and parallel to the general Caucasian trend contained 10-94 ppb $\mathrm{Au}$, concentrations that exceed normal background levels for most sedimentary rocks. The results showed as much as 66, 94, 68, and $87 \mathrm{ppb} \mathrm{Au}$ in zones 1 through 4.

Three extremely anomalous occurrences, termed Bendena, Gelia and Thorium, were identified. Although there might be more of such occurrences, accessibility issues prevented study of many altered locations within the Stori River valleys. Recent 
publications exist on the Stori Thorium occurrence [11] and thus only a summary of the existing information is given in this paper. The thorium occurrence is located in the northern part of the district. It is characterized by high concentrations of thorium in association with carbonate quartz-plagioclase veins, which cut Pliensbachian shales that are about $20-30 \mathrm{~cm}$ in thickness. Concentrations of Th in these veins vary from 31 to $3,882 \mathrm{ppm}$. In addition to thorium, anomalous $\mathrm{Bi}(57-4,806 \mathrm{ppm})$ and $\mathrm{Y}$ (75-4,345 ppm) are also recognized in the mineralized zone. These types of thorium deposits are known in many regions of the world, such as described by Staatz [12] in many locations in the USA [13].

The Gelia mineral occurrence is exposed in the central part of the Stori district (Fig. 9), in the Gelia ravine, and is located about $200 \mathrm{~m}$ above the main road. It includes a copper-rich pyrrhotite-chalcopyrite-quartz vein formed within a wide fault zone and is surrounded by haloes of quartz-sericite-chlorite alteration. The vein ranges in thickness from $5-11 \mathrm{~m}$ and can be traced continuously towards the ravine for $80-90 \mathrm{~m}$. Beyond the ravine, due to a rocky cornice, tracing of the vein is not possible, but there is a 250 -m-long section of intensely oxidized rock, which suggests additional $\mathrm{Fe}-\mathrm{Cu}$ mineralization at depth.

The Gelia vein, which is clearly the product of a metalliferous hydrothermal event, was studied in detail. The main sulfide mineral in the massive sulfide is pyrrhotite, with subordinate chalcopyrite, pyrite, and arsenopyrite. A range of metals was measured for 15 samples of the massive quartz-pyrrhotite-chalcopyrite mineralization from the vein by ICP-MS and the 1F15 method (Fig. 8). The range of concentrations is as follows: 350-1,660 ppm Cu, 11-33 ppm Pb, 25-35 ppm Zn, 1,500-6,400 ppm As, 124-295 ppm Co, and $25-35 \%$ Fe. Gold and silver were generally not detected in the massive ores, although two samples from vein selvages did contain 1.41 and $4.56 \mathrm{ppm} \mathrm{Au.}$ The results from the Gelia vein chemical analyses indicate consistent enrichments in $\mathrm{Fe}, \mathrm{Cu}$, and $\mathrm{As}$, with some potential for $\mathrm{Au}$ mineralization. This element suite is consistent with that formed in hydrothermally altered zones surrounding porphyry deposits [10].

Artana distric: There are ten known mineral occurrences within the Aratana district. Among these, the best studied occurrences are Samchedlo, Englisuri, and Siptis-Tskali.

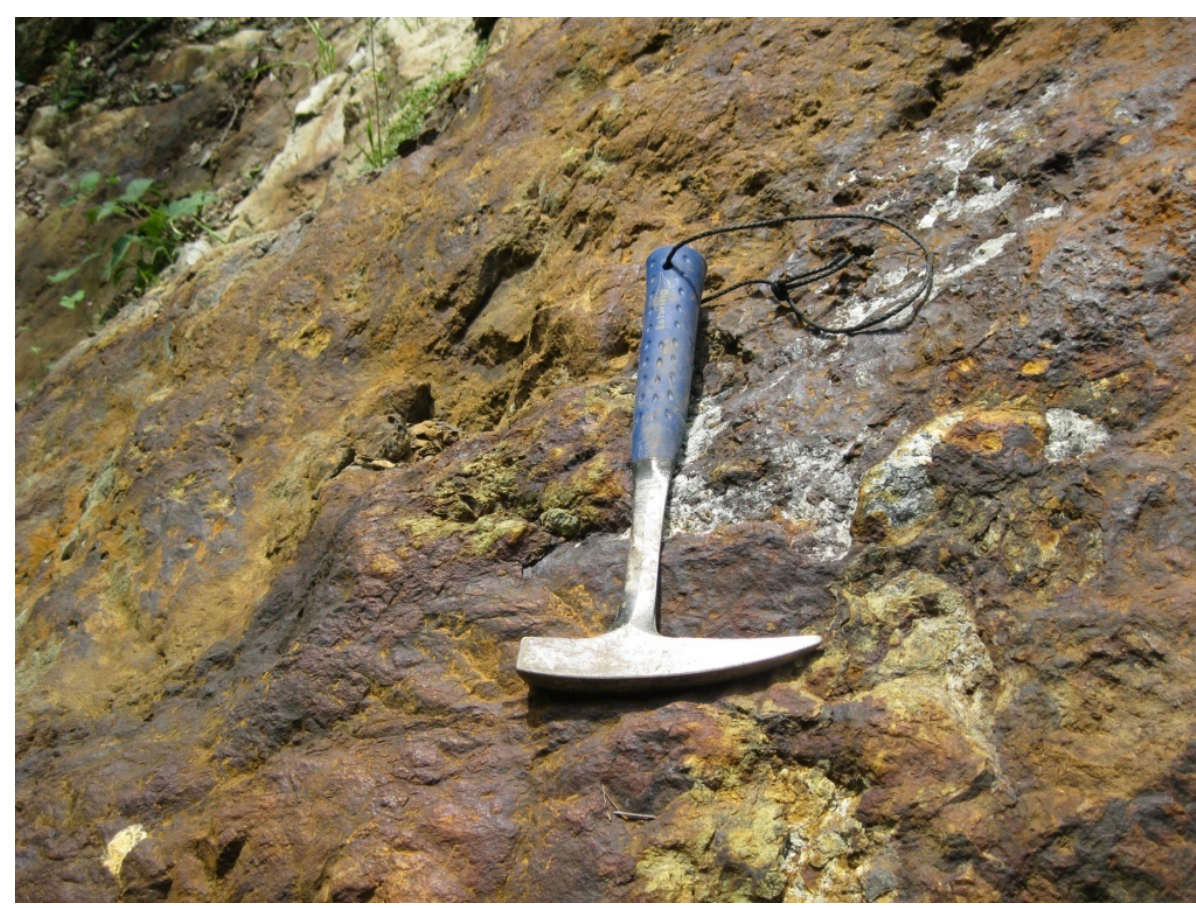

Fig. 9 Fragment of quartz-pyrrhotite-chalcopyrite vein of Gelia ore occurrence. 
The mineralized vein at Samchedlo is situated in the rocky cornices of the Okhotis-Tskali River valley, 12 $\mathrm{km}$ north of the village of Artana. The vein is localized in a fault gouge zone, with a general strike parallel to Caucasus Range and a shallow dip of $20-30^{\circ}$. The country rocks are those of the Pliensbachian shales. The thickness of the mineralized vein is $2-2.5 \mathrm{~m}$, and can be traced along strike for about $500-550 \mathrm{~m}$. The central part of the vein contains massive chalcopyrite and pyrrhotite and is highly brecciated. In addition to these main sulfide minerals, small amounts of galena, sphalerite, ilmenite, and cobaltine are present.

The vein at Samchedlo was explored by a 58 -m-long adit and a $405 \mathrm{~m}$ drillhole, which intersected a sulfide mineralized fault zone at a depth of 290.5-295.0 m. In the 291.4-292.1 $\mathrm{m}$ interval, massive chalcopyrite-pyrrhotitic mineralization was identified, which is mineralogically and chemically identical to the mineralization throughout the adit. According to work by the Department of Geology, the average content of metals in the deposit is $2.08 \% \mathrm{Cu}, 0.85 \% \mathrm{Zn}$, and $0.65 \% \mathrm{~Pb}$ [14].

During our research at Samchedlo we collected and analyzed 18 samples by ICP-MS. Resulting data for the massive sulfides indicated $1.40-3.54 \% \mathrm{Cu}, 19.6-61.4 \%$ Fe, 17-21 ppm Pb, 173-610 ppm Zn, 118-1,040 ppm Co, 8-22 ppm Cd, 15-50 ppm Bi, and 2-4 ppm Ag. In the massive chalcopyrite-pyrrhotite mineralization, significant concentrations of gold were consistently detected at values between 0.32 and $1.31 \mathrm{ppm}$.

The vein at Englisuri is located on the rocky cornices of the Okhotis-Tskali River valley, and is about $1.5 \mathrm{~km}$ from the Samchedlo deposit. It is also situated in a fault gouge that is parallel to the general trend of the range and dips about $50^{\circ}$, with thickness of 4.5-5.0 m. The vein and associated fault zone occurs in brecciated, chloritized, and silicified Pliensbachian shales. In the middle of the alteration zone, the sulfide-rich vein is 1.4-1.8 $\mathrm{m}$ in thickness. It appears as pyrrhotite-chalcopyrite in lenses, pods, and quartz veinlets, with also a small amount of pyrite, galena, and sphalerite. A 38-m-long adit intersects the mineralization. Along the southern side of the vein, experience intense silicification and malachite staining are evident in an area of older adits developed by British prospectors.

Our data for the vein at Englisuri were collected from 12 samples that were analyzed by ICP-MS. Resulting data for the massive mineralization ranged from 1.09-5.14\% Cu, 16.4-61-4\% Fe, 6-44 ppm Pb, 140-8,540 ppm Zn, 118-1,040 ppm Co, 8-22 ppm Cd, 19-75 ppm Bi, 12-28 ppm As, and 2-4 ppm Ag. In a selvage of the quartz-pyrite-chalcopyrite veinlets, as much as $3.09 \mathrm{ppm}$ Au was detected. The gold was again only determined using digestion method $3 \mathrm{~B}$ prior to ICP-MS analysis

The Siptis-Tskali mineral occurrence outcrops in the same name river valley, $1 \mathrm{~km}$ to the north of the confluence of the Okhotis-Tskali River with the Siptis-Tskali River. It is hosted in Pliensbachian shales along a shear zone, parallel to the general Caucasian trend. Mineralization appears as a complex configuration of veins and lenses dominated by massive pyrrhotite. The thickness of the mineralized zone ranges from 0.4-3.7 m, and it can be traced for $250 \mathrm{~m}$. Mineralized bodies are primarily fine-grained pyrrhotite, with scattered coarser grains of chalcopyrite. The selvages of the bodies are brecciated and quartz-chalcopyrite-pyrite-pyrrhotite stockworks and disseminations are common. Based upon work by the Department of Geology, the average content of metals in the occurrence includes $1.35 \% \mathrm{Cu}, 0.05 \% \mathrm{~Pb}$, and $0.9 \% \mathrm{Zn}$. The mineralized zone was drilled to $400 \mathrm{~m}$ and a wide interval from $285-380 \mathrm{~m}$ cut a brecciated zone with pyrite mineralization, which averaged $0.05 \%$ $\mathrm{Cu}$ and $0.01 \% \mathrm{~Pb}+\mathrm{Zn}$ [12]. Our new data for 12 samples of the mineralization from the Siptis-Tskali occurrence indicated average concentrations of 4,120 g/t, ppm Cu, 115 ppm Pb, 3,075 ppm Zn, 202 ppm Ni, 274 ppm Co, 255 ppm Mn, 19.7\% Fe, 1.2 ppm As, 1 ppm Ag, and 5 ppb Au.

The Abano ore occurrence is exposed on the 
southern slope along the road connecting Kakheti with Tusheti Pass, at an altitude of 2,500-2,700 m. Mineralization is localized in a wide shear zone, generally following the Caucasian trend, within the Toarcian sandstones and shales. It is a 700-m-thick section with 12 mineralized zones, which range from 0.8-12.5 $\mathrm{m}$ in thickness. The zones are traced for distances of between 250 and $1,400 \mathrm{~m}$ [15]. The mineralized zones are intensely brecciated and weathered on the surface. Mineralization is represented by galena, sphalerite, chalcopyrite, pyrite, and locally marcasite as veinlets, disseminations, small pods, and lenses. Secondary minerals that can be observed include anglesite, cerussite, and locally malachite. The mineralization is very irregularly distributed with sulfide-rich and barren areas showing sharp contrasts.

One of the Abano mineralized zones, with a thickness of $2.8 \mathrm{~m}$, was studied by us in detail. The zone is dominated by abundant silicified and carbonatized shale gouge, where pyrite-galena-sphalerite mineralization is well developed. The sulfides occur as massive lenses, pods, veins, or disseminations. Our analytical results for 12 samples indicated anomalies of 252-786 ppm $\mathrm{Cu}$, $1.78-4.41 \% \mathrm{~Pb}, 3.43-4.41 \% \mathrm{Zn}, 15.8-30.9 \% \mathrm{Fe}$, 35-397 ppm As, and 7- 21 ppm Ag.

The Lechuri mineral occurrence is located south of the village of Lechuri, approximately $1.5 \mathrm{~km}$ up a tributary of the Stori River, we observed pyrite-polymetallic mineralization about $2 \mathrm{~m}$ above rocky cornices in the riverbed. The occurrence is covered by alluvial-colluvial deposits that makes it difficult to trace the mineralization for any considerable distance or to estimate thickness. The SE slopes of the valley expose shales that are hydrothermally altered to quartz-chlorite-sericite assemblages, which are cut by sulfide-rich quartz veins of various orientations. A zone of about $22-25 \mathrm{~m}$ in thickness can be traced approximately for more than 1 $\mathrm{km}$ along strike, with a dip of $20-25^{\circ}$, and it is localized within the Toarcian shales and sandstones.
Six samples were taken from massive sulfide mineralization and four from sulfide-bearing quartz veins from the Lechuri occurrence. Results from the ICP-MS analyses of the massive sulfide showed 20-80 ppb Au, 5-16 ppm Ag, 40-292 ppm As, 7-28 ppm Bi, 9-26 ppm Cd, 7-21 ppm Co, 300-1,470 ppm Cu, 1,850 ppm- $>1 \% \mathrm{~Pb}$, and $3,380 \mathrm{ppm}->1 \% \mathrm{Zn}$. Metal concentrations are similar for the quartz-sulfide veins and average $80 \mathrm{ppb} \mathrm{Au}, 5$ ppm Ag, 292 ppm As, 9 ppm Bi, 9 ppm Cd, 7 ppm Co, 696 ppm Cu, 9,010 ppm Pb, and $\mathrm{Zn}>1 \% \mathrm{Zn}$. According to the geochemical signature, mineralization style, and geotectonic setting, the Lechuri mineral occurrence shows similarities to the well-studied Philizchay pyrite-polymetalic deposit, which emphasizes the importance of further research at Lechuri.

\subsection{Tusheti Region}

The Ilurta district is located in Tusheti, on the northern slope of the Greater Caucasus, in the Gometsari Alazani tributary to the Ilurta River, and covers an area of $15 \mathrm{~km}^{2}$. The mineralized rocks are represented by Toarcian shales and sandstones, which are about 300-m-thick intensely crushed and brecciated, and dip $20-30^{\circ}$. Some parts of the district show phyllic (quartz-sericite-chlorite) alteration of shales, with five 0.5 - to 4-m-thick mineralized zones that can be traced for about 200-600 m along strike. They mostly comprise quartz veinlets and sulfide minerals, which are represented by pyrite, chalcopyrite, galena, sphalerite, and arsenopyrite. Existing data showed metal concentrations for the occurrences of $0.3-4.0 \%$ $\mathrm{Pb}, 0.4-8.12 \% \mathrm{Zn}$, and $0.1-0.34 \% \mathrm{Cu}$ [12]. We analyzed ten samples by ICP-MS, which showed very variable metal concentrations. These included 55-3,800 ppm Cu, 90-5,950 ppm Pb, 1,200-8,590 ppm $\mathrm{Zn}$, and 10-212 ppm As. Elevated concentrations of silver and gold were not measured.

The Tebulo district is located in Tusheti, to the northwest of the Ilurta district and on the southern slope of Tebulo Mountain, at 2,700-2,900 m altitude 
and covering about $22 \mathrm{~km}^{2}$ in area. According to toponym the area is referred to as an "ore throat" in Tush dialect, which means ore place. The ore-bearing rocks are mainly Pliensbachian terrigenous sediments, which are intruded by gabbro-diabase and diorite bodies. The area is located at the intersection of the Caucasian and Transcaucasian regional deep faults, which makes the district highly prospective. Sedimentary rocks form an overturned NW-SE, $135^{\circ}$ striking anticline facing south and dipping $70^{\circ} \rightarrow 45^{\circ}$; a 220-m-thick steeply dipping brecciated zone with a strike of $175^{\circ}$ and dip direction of $75^{\circ} \rightarrow 85^{\circ}$, cuts the anticline.

The small ridge situated in the central part of the district divides the area into two parts. In the western part, on the NW slope of the Dakvekhis-Khevi River, there are eight parallel mineralized bodies exposed. They are hosted by gouge in silicified shales and are cut up by quartz-, pyrite-, chalcopyrite-, and galena-bearing veinlets. The thickness of these bodies varies from 1.5-6 m, and each is separated by layers of brecciated shales, cumulatively forming a zone as thick as $35 \mathrm{~m}$. The 48 samples from the mineralized zone were analyzed for $\mathrm{Au}, \mathrm{Ag}, \mathrm{Cu}, \mathrm{Pb}$, and $\mathrm{Zn}$ at the laboratory of CMG Gold Ltd. The analyses showed
$0.1-2.10 \% \mathrm{Cu}, 0.01-0.92 \% \mathrm{~Pb}, 0.01-0.98 \% \mathrm{Zn}$, and 4.0-21.1 ppm Ag. Gold was detected in almost all samples, with concentrations ranging from 30-640 ppb, which indicates precious metal potential for the western part of the district.

In the eastern part of the district, shales are highly crushed, brecciated and silicified, and rocky cornices on the southeastern side of Tebulo Mountain are pervasively altered to quartz-sericite-chlorite, an assemblage typically noted on the top of porphyry deposits. From the base of the cornices, for 250-300 m downward, on the NW slope of Tebulo River, copper-rich polymetallic mineralization was in veins of 1.3-1.7 $\mathrm{m}$ in thickness outcrop (Fig. 10). The extent of veining is difficult to judge because of rock slides covering some of the area. Large mineralized boulders, $1.0-1.5 \mathrm{~m}^{3}$ in size, are eroded from these veins and are present in several places on the valley floor.

Fourteen samples of massive pyrite-polymetallic mineralization from Tebulo occurrences were analyzed by ICP-MS. The results showed 500-725 ppm Cu, $1,300 \mathrm{~g} / \mathrm{t} \sim 1,430 \mathrm{ppm} \mathrm{Pb}$, and $>1 \% \mathrm{Zn}$ in all samples. Average concentrations of other elements included 25.3-30.9\% Fe, 452.3-745.4 ppm Cd, 82.8-146.7 ppm Co, 72.3-81.9 ppm Bi, 56-721 ppm Mn, 18.4-21.7 ppm

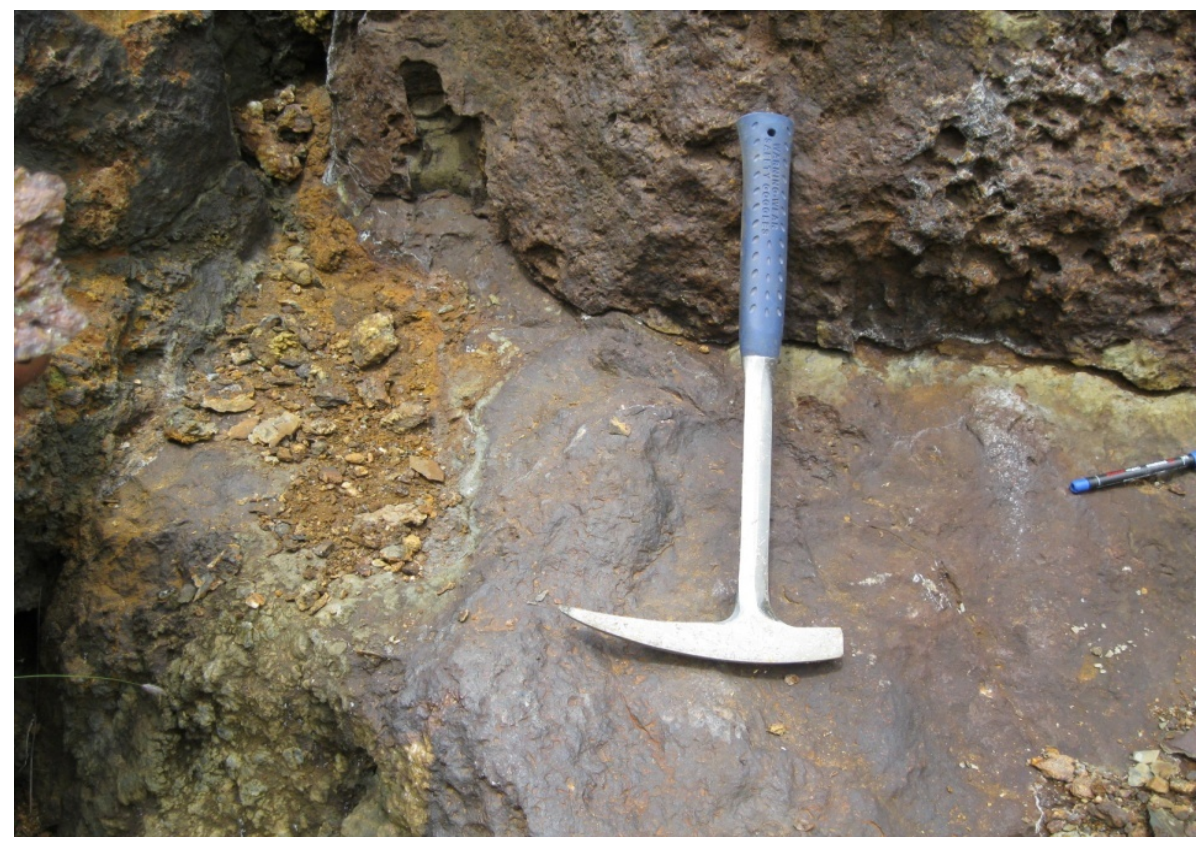

Fig. 10 Fragment of copper-rich polymetalic ore from the Tebulo ore mineralitation district. 
$\mathrm{Ni}$, and 178.8-219.0 ppm As. Silver and gold were detected in all samples, with ranges 8.19-10.57 ppm Ag and the 29-141 ppb Au.

Thus, a wide range of metals with anomalous concentrations, including $\mathrm{Ag}, \mathrm{Au}, \mathrm{Cu}, \mathrm{Pb}, \mathrm{Zn}, \mathrm{Co}, \mathrm{Cd}$, $\mathrm{Bi}, \mathrm{Mn}$, and $\mathrm{Fe}$, are present in the Tebulo district. The scale of the mineralization appears very large, but it requires further detailed study. The mineralization shows important similarities to that at Philizchay and Katekh in its characteristics and anomalous metal signature $(\mathrm{Cu}, \mathrm{Pb}, \mathrm{Zn}, \mathrm{Fe})$. Thus, it should be considered as a pyrite-polymetallic mineralization type. It should be noted that, unlike many of the other mineralized areas discussed here, elevated gold concentrations were observed in Tebulo district.

\section{Discussion}

The conducted field work showed that the Eastern Greater Caucasus in Georgia generally comprises intensely folded and overturned to south Lower-Middle Jurassic shales, sandstones, and thick volcanogenic-sedimentary series. They follow the general Caucasian trend and can be traced far to the southeast and northwest. The geological data all suggest that the entire rock sequence accumulated within a marginal sea environment during a period of extension and destruction of Paleozoic basement.

The study has shown that during almost the entire evolution of the Kakheti and Tusheti regions of the Greater Caucasus, intense magmatic processes took place. Evaluation of all data indicates three stages of magmatic activity occurred. The first magmatic activity was related to extension and subsidence in the Early Jurassic, when rhyolitic, through dacitic, and to andesitic-basaltic magma was formed and during progressive fractional crystallization. The second important activity was related to extension of newly formed crust, with Bajocian basic intrusions emplaced into Lower Jurassic-Aalenian sediments and a dike system of gabbro-diabases was formed. The third magmatic event is associated with folding and uplifting during which multiphase dioritic plutons intruded into the sedimentary rocks and caused widespread hydrothermal alteration, including development of propylitic and phyllic assemblages and associated sulfide mineralization.

Our metallogenic study carried out in the research area has shown that a wide range of mineral occurrences, largely in terms of composition and style, is represented. Most are just locally exposed and the potential for important resources remaining to be discovered at shallower depths is high, particularly under the cover of sedimentary formations and where altered zones are exposed at the surface. According to a number of parameters, these occurances are hydrothermal in origin and are likely genetically linked to productive magmatic centers [10].

Zones of non-ferrous metal occurrences are separated in the eastern Greater Caucasus into southern and northern areas by Kharashvili [16] and Akimidze et al. [14]. According to these workers, the southern zone hosts local copper-pyrrhotite mineralization occurrences (e.g. Samchedlo, Englisuri, Katsdag), whereas the northern one hosts metal sulfides (pyrite, sphalerite and galena) occurrences (e.g., Abano, Ilurta, Tebulo). They believed that formation of the different occurrence types was caused by different hydrothermal fluid sources and report that the chalcopyrite-pyrrhotite occurrences were genetically linked to basic and intermediate magmatism, and the pyrite -polymetallic ones were associated with felsic magmatic activity [17]. Fieldwork conducted by our group, in contrast, showed that the sulfide composition of hydrothermal occurrences reflects the distance between the causative magmatic center and the site of mineralization. As numerous experiments have shown [18-20] for a hydrothermal fluid of the same composition and pressure regime, chalcopyrite precipitation will take place at temperatures that are about $100{ }^{\circ} \mathrm{C}$ higher than those for sphalerite and galena precipitation. We believe that the same hydrothermal fluid closer to a magmatic center will generally deposit chalcopyrite, 
whereas as it travels farther away, sphalerite-galena bodies will preferentially form.

\section{Conclusions}

Thus, from the conclusions of our metallogenic research, it can be seen that numerous mineral occurrences in the Eastern Greater Caucasus Georgian segment formed from similar magmatic-hydrothermal fluids, but under different temperature regimes. There is no doubt that Artana, loduani, Chelti, and other similar mineral occurrences are small-scale when compared to many developed world-class metal deposits. However, the Stori and Tebulo districts have potential to develop large-scale resources, as supported by the extensive development of quartz-sericite-chlorite-pyrite and albite-epidote-chlorite-pyrite alteration zones that typically are characteristic of porphyry deposits.

The Lechuri mineral occurrence, which was discovered during this research, is of great interest. The mineralization shows important similarities to the Filizchay pyrite-polymetallic deposit based on geology, mineralogy, and geochemistry. Because of this, it is necessary that further detailed study of the mineralization be conducted. This present research has noted for the first time the presence of elevated gold in the region. It should be highlighted that the Tebulo district, where gold anomalies were determined in massive polymetallic bodies, is associated with strongly silicified zones, which is an important result of our research.

In conclusion, we note that it is necessary to undertake more detailed metallogenic research in the Eastern Greater Caucasus Georgian segment in the future, because many significant problems still exist and important mineral deposits, such as those in neighboring Azerbaijan and Dagestan, may be present, but concealed, in areas of shallow cover.

\section{Acknowledgments}

The authors would like to thank the Rustaveli
National Science Foundation of Georgia for funding the project (\#GNSF/ST09-1071-5-150) through which the research work was conducted in the Kakheti and Tusheti regions of the Greater Caucasus and Geological department of the Taiwan National University, where part of analytical work was conducted. Special thanks go to Prof. Richard Goldfarb (USA), for his valuable advices and comments, and editorial input that helped the better presentation of the paper.

\section{References}

[1] Novruzov, N. A., and Agaev, S. A. 2009. "Mineralogical-Geochemical Zonality of Filizchay Pyrite-Pollymetalic deposit (Greater Caucasus)". In Geologic Science and Industrial Development of Kazakhstan, Alma-Ata, 211-5. (in Russian)

[2] Bogush, I. A., and Kurbanov, M. 1999. "Genetic Model of the Kizil-Dere Copper-Pyrite Deposit." Bulletin of North Caucasian Region 4: 94-100. (in Russian)

[3] Okrostsvaridze, A., and Tormay, D. 2011. "Evolution of the Variscan Orogenic Plutonic Magmatizm: The Greater Caucasus." Journal of Nepal Geological Society, Special Issue 403: 45-52.

[4] Gamkrelidze, I. P. 1986. "Geodinamic Evolution of the Caucasus and Adjacent Areas in Alpine Time." Tectonophysics 127: 261-77.

[5] Gamkrelidze, I. P. 2003. "Geological Map of Georgia, 1:500 000."

[6] Topchishvili, M. 1996. "Stratigraphy of Lower Jurassic Formations of Georgia." Bull of Acad of Scien Georgia 108: 205-16.

[7] Okrostsvaridze, A., Bluashvili D., Gagnidze N., and Boichenko, G. 2012. "New Interpretation of the Stori Suite 'Arkoze Sandstones' of the Greater Caucasus Kakheti Segment." Mining Journal 24: 12-22.

[8] Akimidze, K. 2010. "Late Pliensbachian-Early Toarcian Volcanism of Trans-Alazani Kakheti." Proceedings of the Al. Janelidze Institute of Geology, New Series 125: 164-72.

[9] Chikhradze, G. 1976. "On the Lithostratigraphy of the Lower-Middle Jurassic Formations of the Trans-Alazani Kakheti." Bulletin of the Acad of Sciences of Georgian SSR 82: 637-64.

[10] Ridley, J. 2013. Ore Deposit Geology. London: Cambridge University Press.

[11] Okrostsvaridze, A., Akimidze, K., and Bluasvili, D. 2011. "The First Data on Industrial Concentration of Thorium and Bismuth in Hydrothermally Altered rocks of the Stori 


\section{Greater Caucasus, Georgia Republic}

Canyon, Greater Caucasus." Bull. Georg. Acad. Scinces 5: 76-82.

[12] Staatz, M. N. 1974. "Thorium Veins in the United States." J. Economic Geology 69: 494-507.

[13] Bradley, V. G., Gillerman, V. S., and Armbrustmacher, T. J. 2009. "Thorium Deposit of the United States-Energy Resources for the Future?" US Geological Survey. Circular 1336: 21. Available at URL http://pubs.usgs.gov/circ/1336.

[14] Kharashvili, G. I. 1948. "Mineralogy of Trans-Alazani Ore Field.” Abstract of Kandidat Dissertation, Tbilisi, 27.

[15] Akimidze, K. Bnenidze, G., and Fruidze, M. 1980. "Report of Prospecting Works for 1975-1980 yy, in 1:25 000 Scale, of the Copper-Pyrrhotitic Belt of Kakheti." Funds of Geological Department of Georgian, 235.

[16] Kuchava, E., Melikishvili, T., and Benidze, G. 1983. "Report on General Prospecting Works Results for 1980-83 yy, in 1:25000 scale, in the Interfluve of the rr.
Chelti-Alazani." Funds of Geologic Department of Georgian, 214.

[17] Bogdanov, Y. V., and Kutyrev, E. I. 1973. "Classification of Stratified Copper and Lead-Zinc Deposits and the Regularities of Their Distribution." In Ore in Sediment. International Union of Geological Sciences 3: 55-63.

[18] Czamanske, G., and Rye, R. 2008. "Experimentally Determined Susfur Isotope Fractionatins between Sphalerte and Galena in Temperatute Gange 600 Degrees to $275^{\circ} \mathrm{C}$." J. Cosmochimal Acta 50: 651-62.

[19] Seal, R. 2006. "Sulfur Izotope Geochemistry of Sulife Minerals." J Reviews in Mineralogy and Geochemistry 61: 633-77.

[20] Chane-Ching, J., Gillorin, A., Zaberca, O., Balocchi, A., and Marie, X. 2011. "Highly Crystallized Quaternary Chalcopyrite Nanocrystals via a High-Temperature Dissolution-Repreciptation Route.” J. Chemical Communcations 18 (47): 5229-31. 